\title{
Effect of Month and Season of Birth on Milk Quantity and Quality of Holstein Friesian Cows in Kabul Bini Hisar Dairy Farm
}

\author{
Shaour Gul Faqiri* ${ }^{* 1}$ and Gul Mohammad Tanin ${ }^{1}$
}

${ }^{1}$ Department of Animal Production, Faculty of Veterinary Science, Kabul University, Afghanistan

Received: 01 April, 2017; Accepted: 02 May, 2017; Published: 12 May, 2017

*Corresponding author: Shaour Gul Faqiri, Department of Animal Production, Faculty of Veterinary Science, Kabul University, Afghanistan; E-mail: dr_faqiri@yahoo.com

\begin{abstract}
AEffect of calving month and season on productive traits of Holstein dairy cows

In Kabul Bini Hisar Dairy farm

Productive data on 305 days lactation period for 49 Holstein dairy cows, which were collected during one month from dairy cattle in Beni Hisar Farm in Kabul province using recorded data from 1389 to 1392 years, were used to estimate the effect of calving month and season for the purpose of estimating the correlation between milk yield, fat production and fat percentage of the Holstein dairy cows. General linear model (GLM) procedure and SPSS software were used for the estimation of the effect calving month and seasons. The results showed calving month influenced significantly on productive traits $(\mathrm{P}<0.05)$. The greatest milk and fat production $(\mathrm{kg})$ were observed in dairy cows that calved in December. In addition, dairy cows that calved in October had the greatest fat percentage totally, the results showed, animals that calved in fall season had greater performance than the others. Naturally, milk production of these animals reached production peak in winter when the weather and nutritional conditions are suitable for production.
\end{abstract}

Keywords: Calving month; Calving season; Productive traits correlation

\section{Introduction}

High productive Holstein Friesian cattle are famous dairy cattle all over the world. As the hereditary traits can only be expressed under favorable climatic- geographic conditions, so because of this reason they show different performances in different prevailing conditions. In South Korea, Lee and Han on the basis of their investigations reported that cows calved in late winter showed better milk performance [1]. This is because that they may receive better nutrition conditions in spring and summer. Amasaib, et al mentioned that in Sudan the best calving time for
Holstein cows is winter as they showed high milk performance [2]. Auradkar, Changunda and Komatwar, et al reported that season of birth has high impact on lactation length [3-5]. In addition birth season significantly influence daily milk production over the lactation period as cows with summer delivery showed less milk yield. Mostret, et al wrote that the effect of caving season on the lactation curves displayed the requirement for different management approaches [6]. Dedkov, et al and Saw, et al reported that the calving year had significant impact on milk yield during the whole lactation period $[7,8]$. Rekik and Tekel considered that the season of delivery has significant impact on milk amount during the peak of lactation in Holstein cows $[9,10]$.

It should be pointed out that Faryadi, et al found that the phenotypic correlation between milk yield and milk fat and protein amounts and fat percentage is $0.71,0.92$ and -0.17 , respectively for Iranian Holstein cows [11]. Similarly, Rostami, et al reported that the phenotypic correlation between milk production and fat percentage is -0.46 , milk yield and fat amount is 0.64 and fat amount and percentage is 0.3 for Sari province Holstein cows [12].

As, Holstein cattle show different milk production both quantitatively and qualitatively in different areas, so it was decided to investigate the Holstein cattle performance in Kabul Bini Hisar dairy cattle farm.

The objectives of this study are to estimate the effect of calving month on production traits of Holstein cows, find the relationship between milk yield and calving month and determining the best month (season) of birth. 


\section{Methods and materials}

Productive data for 5300 records of Holstein dairy cows, which were collected from one dairy herd in Kabul province from 2010 to 2013, were used to estimate the effect of calving month on milk, fat and fat percentage of dairy cows .This investigation was conducted in Kabul Bini Hisar dairy farm using the secondary data which is collected from the herd book. For data collection performance records of the mentioned cows from 1389- 1392 years (correspondent to 2010-2013) are analyzed and the same time observation and interviews with farm professional cadre also carried out [13-15]. During one month the data have been collected for 3 important productive traits (milk yield, fat amount and percentage) for 305 lactation days. All the cows were kept under closed and pasture production system.

Without taking into consideration the age and body condition of the cows, management, raising and feeding conditions for all cows were the same but in the winter season all the cows were fed with concentrate (3-4 kg cotton cake+ silage and dried fodder) and in summer season the cows was taken into the pasture for grazing. It is mentionable that the research was carried out only for the effect of calving month on milk, and fat percentage of dairy cows but not includes the impact of lactation length. For data analysis GLM and SPSS soft and the following model is used:

Where:

$$
Y \mathbf{i j m}=\boldsymbol{\mu}+\mathbf{M i}+\mathbf{S} \mathbf{j}+\mathbf{L k}+\mathbf{Y l}+\mathbf{e i j m}
$$

Yijm= number of observations from traits, $\mu=$ total average,

$\mathrm{Mi}=$ effect of delivery month $(\mathrm{i}=1-12)$,

$\mathrm{Si}=$ effect of birth season $(\mathrm{j}=-4)$,

$\mathrm{Yl}=$ effect of calving year ( $\mathrm{l}=2010$ - 2013), and

Eijm= effect of other factors.

Phenotypic correlation and descriptive statistics estimations are performed by SPSS and EXCEL soft. Test of Duncan's and ANOVA used to compare the averages.

\section{Results}

\section{The effect of birth month on milk quality and quantity}

The study connecting to the effect of calving month on milk production showed that best milk performance observed for those Holstein cows which freshened Aqrab (November) month, (Table1). In this month $16 \mathrm{Kg}$ as daily average is produced, which is $3 \mathrm{Kg}$ more than the total average $(13 \mathrm{Kg})$. Minimum milk production is seen in the month of Sunbula (September), $101.41 \mathrm{Kg}$, which is around $6 \mathrm{Kg}$ less than the total average. Connecting to fat amount, cows freshened in Dalwa (February) showed the highest fat yield (157 $54.79 \mathrm{Kg}$ ), but in milk percentage, cows delivered in Sunbula (September) and Dalwa (February) should highest percentage of milk fat than cows calved in other months.

Table 1: Average milk yield, fat percentage and total fat amount in different months

\begin{tabular}{|l|c|c|c|}
\hline \multicolumn{1}{|c|}{ Months } & Milk yield (Kg) & Fat (\%) & Total fat (Kg) \\
\hline Hamal (April) & $\mu \pm$ SD & $\mu \pm$ SD & $145.91 \pm 42.87$ \\
\hline Sawr (May) & $12.5 \pm 2.66$ & $4.08 \pm 1.07$ & $125.61 \pm 21.16$ \\
\hline Jawza (June) & $12.5 \pm 2.66$ & $3.44 \pm 0.41$ & $136.44 \pm 11.03$ \\
\hline Saratan (July) & $13 \pm 2.34$ & $3.6 \pm 0.35$ & $142 \pm 30.82$ \\
\hline Asad (August) & $13 \pm 2.75$ & $3.92 \pm 0.8$ & $127.77 \pm 13.68$ \\
\hline Sunbula (September) & $14 \pm 2.16$ & $3.25 \pm 0.23$ & $133.15 \pm 12.89$ \\
\hline Meezan (October) & $10 \pm 1.41$ & $4.44 \pm 1.04$ & $134.05 \pm 53.66$ \\
\hline Aqrab(November) & $11 \pm 2.82$ & $3.9 \pm 0.56$ & $140.83 \pm 41.03$ \\
\hline Qaws (December) & $16 \pm 0.89$ & $3.08 \pm 0.21$ & $134.73 \pm 39.46$ \\
\hline Jadi (January) & $12.67 \pm 1.52$ & $3.53 \pm 0.77$ & $165 \pm 0.00^{*}$ \\
\hline Dalw (February) & $14 \pm 0.00^{*}$ & $4 \pm 0.00^{*}$ & $157 \pm 54.79$ \\
\hline Hoot (March) & $11.4 \pm 2.6$ & $4.55 \pm 1.3$ & $128.5 \pm 1085$ \\
\hline *The data shown above is only from the record of one cow and not all cows, so it is ignored. & $3.21 \pm 0.52$ & \\
\hline
\end{tabular}




\section{Effect of calving season on milk quality and quantity}

The study showed that cows delivered in winter had the best performance from the view point of production and fat percentage, $148.3841 .95 \mathrm{Kg}$ and $4.041 .13 \%$, respectively, and cows that had calved in autumn showed the best productivity in terms of milk yield, $14.182 .52 \mathrm{Kg}$, that's as much as $1.180 .01 \mathrm{Kg}$ higher than the general average of the herd (Table 2).

Table 2: Milk yield, fat percentage and total far in different seasons

\begin{tabular}{|l|c|c|c|}
\multicolumn{1}{|c|}{ Seasons } & Milk yield (Kg) & Fat (\%) & Total fat (Kg) \\
\hline & $\mu \pm$ SD & $\mu \pm$ SD & $\mu \pm$ SD \\
\hline Spring & $12.65 \pm 2.42$ & $3.71 \pm 0.72$ & $135.95 \pm 28.67$ \\
\hline Summer & $12.83 \pm 2.62$ & $3.70 \pm 0.77$ & $135.80 \pm 23.32$ \\
\hline Autumn & $14.18 \pm 2.52$ & $3.35 \pm 0.53$ & $137.93 \pm 38.11$ \\
\hline Winter & $12.44 \pm 2.5$ & $4.04 \pm 1.13$ & $148.38 \pm 41.95$ \\
\hline All year & $13 \pm 2.51$ & $3.71 \pm 0.8$ & $138.65 \pm 31.89$
\end{tabular}

Table 2 shows that fat yield trait has the highest diversity coefficient and fat percentage the least.

\section{Effect of calving year on milk quantity and quality}

Table 3 shows that the highest milk production is corresponding to 1393 year (2014) that is $15.470 .91 \mathrm{Kg}$ and least amount of milk production in 1390 (2011), which is 10.711 .79 Kg. However, the highest percentage of fat (4.49.03\%) occurred in 1391 (2012)and the lowest percentage of fat (3.15 0.25\%) in 1393(2014). In addition, total amount of fat (151.05 $16.89 \mathrm{Kg})$ produced in 1389 (2010) and the lowest amount (128.58 40.37 $\mathrm{Kg}$ ) in 1390 (2011).

Table 3: Effect of calving year on milk traits

\begin{tabular}{|c|c|c|c|}
\hline Year & Milk yield (Kg) & Fat (\%) & Total fat (Kg) \\
\hline $\mathbf{1 3 8 9}(\mathbf{2 0 1 0 )}$ & $14 \pm 1.41$ & $\mu \pm$ SD & $\mu \pm$ SD \\
\hline $\mathbf{1 3 9 0}(\mathbf{2 0 1 1 )}$ & $10.71 \pm 1.79$ & $3.89 \pm 0.79$ & $128.58 \pm 40.37$ \\
\hline $\mathbf{1 3 9 1}(\mathbf{2 0 1 2 )}$ & $11 \pm 1.51$ & $4.49 \pm 1.03$ & $150.48 \pm 42.36$ \\
\hline $\mathbf{1 3 9 2}(\mathbf{2 0 1 3 )}$ & $12.59 \pm 2.37$ & $3.77 \pm 0.7$ & $142.63 \pm 36.84$ \\
\hline $\mathbf{1 3 9 3}(\mathbf{2 0 1 4 )}$ & $15.47 \pm 0.91$ & $3.15 \pm 0.25$ & $130.87 \pm 9.06$ \\
\hline
\end{tabular}

\section{Phenotypic correlation between milk traits}

Phenotypic correlation expressed the lowest values between the two traits (total milk and fat). Table 4 highlights the phenotypic correlation between all milk traits significant $(\mathrm{P})$.

\begin{tabular}{|c|c|c|c|}
\hline \multicolumn{4}{|c|}{ Table 4: Phenotypic correlation between milk traits } \\
\hline Values & $\begin{array}{c}\text { Milk production } \\
\mathbf{( k g )}\end{array}$ & Fat (\%) & Total fat (Kg) \\
\hline $\begin{array}{c}\text { Milk yield } \\
\text { Fat } \\
\text { percentage }\end{array}$ & 1 & -0.46 & 0.195 \\
\hline \begin{tabular}{c} 
Total fat \\
\hline
\end{tabular} & -0.46 & 1 & 0.669 \\
\hline
\end{tabular}

\section{Discussion}

For native breeds of cattle strategies, there is big need that the climatic- geographic conditions of all provinces should be taken into consideration in different seasons, in order to be able to produce high productive cows to the benefit of farmers and farm owners all over the country. To achieve these goals, first of all three is need for determination of best month and season of production to effectively implement the breeding plans policies and strategies, in order to produce more quality milk.

In this investigation, 49 Holstein cows studied to evaluate the quality and quantity of milk produced in different months and season of the year. In general, milk yield and it's traits were significantly different from each other, but all cows should best performance in the calving month of Aqrab (November) and winter season. It can be pointed out that knowing the favorable month and season for milk production, the amount of quality milk will be increased.

Barash, et al reported that the milk productivity in Holstein cows was the best in Aqrab and Qaws (November and October) that is in agreement with the results of this study. In a study, Mostert, et el found that best calving month for Holstein cows in South Africa is Jawza and Saratan (June and July), as this country located in Southern Hemisphere, so theses months fall in the late autumn and early winter, which confirm the results of this investigation $[16,17]$. In a comprehensive study in four parts of the United States by Norman, et al it was reported that the best months of birth in the four regions are November and December [18]. Rostami, et al reported that the best milk and fat production occurred for cows that had calved in the winter and the best fat percentage for cows that had calved in the summer, that is in agreement with the present outcomes also reported [12]. Dadar, et al reported that the Holstein breed of cattle, milk production is the highest for those cows freshened in fall and winter, which is similar with the results of this study [19].

Fat percentage for Iranian Holstein cows is $0.71,0.92$ and -0.17 , respectively. Rostami, et al found that phenotypic correlation between milk yield and fat percentage for Holstein cows in Sari province was -0.46 , between milk and fat amounts 0.64 , and between fat amount and percentage is 0.3 . Pahlawan, et al reported that phenotypic correlation between milk and fat production and fat percentage is 0.73 and -0.42 , respectively $[12,20]$. These results confirmed by the results of the present research.

In general, for the purpose of production and breed improvement strategies in Afghanistan, it should be found by studies and scientific surveys that when all cattle in Afghanistan 
produce highest amount of milk and milk fat, in order to be able to synchronize the mating, breeding and delivery time At one and the same time it should be understood that under different climatic- geographic conditions of all provinces of the country, when feed production is high and suitable. Proper management programs are also great of need.

For effective realization of the above mentioned points, there is need for enough investment by the government, using international supports and experiences, using all national resources, strengthening and enriching Universities, having enough professional cadres, planning and programming at national level.

\section{Conclusion}

Since there is close relationship between peak of milk production and total milk amounts over a lactation period, because of this delivery month is of great importance in this regard, as after parturition cows reach the peak of milk production in 3-6 weeks and it also should be found that this peak of production occurring in which month and season of the year. This phenomenon can be effectively used the purpose of synchronizing breeding and freshening processes either in winter or in spring. In temperate climatic conditions, Holstein cows show better performance in terms of milk production in winter and for the local breed improvement programs, but to achieve these goals proper management and balanced nutrition is of great importance.

\section{References}

1. Lee DH, Han KJ. Genetic parameters for lactation using the coupling chains Gibbs sampler in multivariate animal models with missing traits in Korean Holstein cattle. J. Anim Sci \& Technol. 2001;43(1):5364.

2. Amasaib EO, Abu Nikhail AM, Fadel Elseed ANMA, Mohamed HE. Effect of Season of Calving and Parity on Some Productive Traits in Pure and Crossbred Cattle in Sudan. Research Journal of Dairy Sciences. 2008;2(1):5-8.

3. Auradkar SK. Genetic and non-genetic factors affecting production and reproduction performance of crossbred cows (H.F. x Sahiwal). PhD dissertation submitted to Marathwada Agric. Univ..,Parbhani. 1999.

4. Changunda MG, Wollny C, Ngwerume F, Kamwanja LA, Makhanbera TP. Environmental factors affecting milk production of H.F. herd in southern Malawi. Proceeding of the International Symposium on Livestock Production Through Breeding and Genetics, (ISLPTBG`95), Harare, p: 17-20.

5. Komatwar SJ, Deshpande AD, Kurkarni AP, Jadau GB. Ultimali AH. Shisode MG. Study on the production traits in H.F. x Sahiwal crossbreds. Indian Jour. Anim. Prod. Manage. 2010;26(3-4):177-181.
6. Mostret BE, Theron HF, Kanfer FHJ. The effect of calving season and age calving on produvtion traits of south African dairy cattle. South African Journal of Animal Science. 2001;31(3).

7. Dedkova L, Wolf J. Estimation of genetic parameters for milk production traits in Czech dairy cattle population. Czech J. anim. Scie. 2001.

8. Sawa A, Piwcznyki D. Somatic cell count and milk yield and composition in Black and white x Hostein-Frission cows. Animal breeding Abstract. 2002.

9. Rekik B, Ben Gara A, Ben Hamonda M, Hammami H. Fitting lactation curves of dairy cattle in deferent type of herds in Tunisia. Livestock production Science. 2003;83(2-3):309-315.

10. Tekel M, Akinci Z, Dogan I, Akean A. Factors affecting the shape of lactation curves of Holstein cows from the Balikesir province of Turkey. J Dairy Sci. 2000;83(6):1381-1386. doi: 10.3168/jds.S00220302(00)75006-5

11. Faryadi, Mehr J. Master Thesis. Faculty of Agriculture, Islamic Open University, Unit of Saveh. 1389.

12. Rostami, Angasy, Sawdagar M, Amiri A. Special Journal of Animal Sciences. 1389;3(3):35-41.

13. Habib MA, Bhuiyan AKFH, Amin MR. Birth weight and it's Non-Genetic effect in Red Chittagong cattle in a closed nuclear herd. Int. J. BioRes. 2009;1(1):35-39.

14. Johnson B, Christensen L. Educational Research. 2nd Edi. Quantitative, Qualitative and Mixed Approaches. USA. Sage Publication. 2014. p. 178-188.

15. Kumar R. Research methodology. 3rd ed. India: South Asia Edition. 2011. p. 35-140.

16. Barash, H., Silanikove, N., Weller, J.I. Effect of Season of Birth on Milk, Fat, and Protein Production of Israeli Holsteins. J. Dairy. Sci. 1996;79(6):1016-1020.

17. Mostert BE, Theron HE, Kanfer FHJ, van Marle-Köster E. Adjustment of heterogeneous variances and a calving year effect in test-day models for national genetic evaluation of dairy cattle in South Africa. S Afr j anim sci. 2006;36(3).

18. Norman HD, Meinert TR, Schutz MM, Wright JR. Age and Seasonal Effects on Holstein Yield for Four Regions of the United States Over Time. J. Dairy. Sci. 1995;78:1855-1861.

19. Dadar M, Mohannadi HA. Research design for the section of research in Animal sciences of the Agricultural Research center of Esfahan province. 1381.

20. Pahlawan R, Muqimi, Abadi A. Special Journal of Animal sciences 1389;3(3):1-12. 